$f i^{n+\infty}$

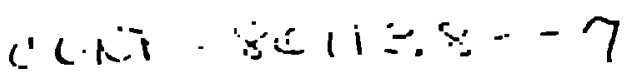

LA-UR $-80-3507$

TITLE: ON CONCEPTS AND LIMITATIONS OF MACROPARTICLE ACCELERATORS USING TRAVELLING MAGNETIC WAVES

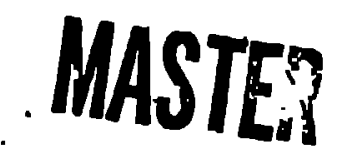

AUTHOR(S): Stefan L. Wipf

SUBMITTED TO: Proceedings of the Conference on Electromagnetic

Guns and Laurichers, San Dlego, CA, Nov. 4-6, 1980

By ecouptance of this srticle, the pulilisherf recorgines that tixe US. Goveriumen! retains a nonerclusive, ruyaley fret liconse 10 publish of poproctuce the mubleshed form of ihis coninguse. fion, or 10 allow oflugn to to so. lor U.S. Gumermente pur. nowis

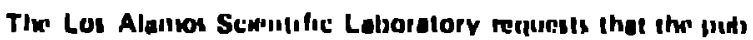

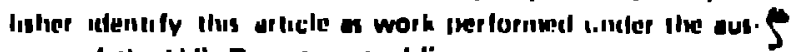
jucus of tho U.S Dupartisent of Lingroy. 


\title{
ON CONCEPTS AND LIMITATIONS OF MACROPARTICLE \\ ACCELERATORS USING TRAVELLING MAGNETIC WAVES
}

\author{
Stefan L. WIpf \\ Los Alamos Scientific Laboratory, MS 764 \\ Los Alamos, New Mexico 87545
}

\section{INTRODUCTION}

The acceleration of macroparticles by traveling magnetic waves and for the purpose of achleving Impact fusion was suggested by Wiaterberg and coworkers. 1,2 The principle is illustrated in Fig. 1. A sultably luagnetized projectile is accelerated by the fleld gradlent of a travelilng magnetic wave. Depending on the sign of the magnetization the projectile rides ahead or behind the crest of the wave; diamagnetic profectiles are pushed away from, paramagnetic ones are pulled towards the fleld maximum of the wave. The force $\left(\mathrm{N} / \mathrm{m}^{3}\right.$ ) exerted on the projectile $1 \mathrm{~s} \mathrm{MdH} / \mathrm{dx}$, with $M$ belng the magnetization per urit volume $(T)$ and $d H / d x$ the locul fleld gradient $\left(\Lambda / m^{2}\right)$. The hiphest accelsration obtalrable $18 \frac{M}{\delta} \frac{d H}{d x}$, with $\delta$ the density of the profectile material.

Naturally, the gpeed $v$ of the magnetic wave must be gynchruntied with the profectile speed $v_{p}$. The synchronisation is autointic if the profectile ides aliead of the maximuin gradicut $\mathrm{dll} / \mathrm{dx}$ where a table position of the profectlie with respect to the magnetic wave $1 \mathrm{a}$ possible: if $v_{p}$ lags behind $v$ the force Increasin and vice verail. The projectile can work with an inducel moment, $M<U$ if a superconductor or $M>0$ if a ferronisgnct, or aje a permanent magnetic moment can be utl]1\%ed. In the latter case $M<0$ is preferrable because the projectilo posfeton ta In a lower field, givling a botter margin to the critical fiold of a supercenductor or a lower magnetofesintive elfect for a nurinal conductor.

T'o my knowlodge nobody has yet bullt Hich an acceleritor. The subject under constderation is at the happy atape where the discussion of 1deas Ia unen: umberud by the Inertia of heavily vastid projects. My presentution ma bo percelved at beling butwoen liand waving and back-ul-an-envalope calculations; 
I would like to think of 1t, flattering myself, as closer to the latter, although to some, dependirig on personal standards, it may seem closer to the former.

The topics to be discussed conceru: 1. the cholce of profectlle; should it be superconducting or ferromagnetic ? 11. the driving acceleration, the magnitude of which determines the length of̈ a IInear accelerator; 111. the guiding acceleration, specially important for a circular accelerator; 1v. sume options with regard to the power supply, especlaliy sulted to the circular version.

At this stage the mentioning of applicatiol $s$ will be peripheral. The eventue.l use of such accelerators could be for 1mpac. fusion; prior to that they will ise tools in the study of hypervelocity physics. Emphasis on efficlency and economics can awalt a future phase of the discussion.

\section{PRO.JECIIILE}

\section{Superconducturs}

The accelerating force Mdil/dx la transmitted by the maximum Lorenta force $f \times f$ that the superconductor can tolerate and this is equal to the forces pluning the flux line lattice. The highest flux pinning forces reported for various superconductors are prescuted in Fig. 2 . As a rule, the superconductor can be used to 1 ta full poreltinl only in the form of fllatnents til a copper matrlx. The pining force varaped over the conposite conductor is therefore lower; it maly be as hiph an $40 \%$ of the values diaplayed In Fig.2. The postible acceleration then reiches into the ranps: of $10^{4}$ to $10^{5}$ clines pravity. Indeed, there hive been proposals that. enviuage accelerations of $3 \times 1 C^{5} \mathrm{~m} / \mathrm{H}^{2}$ for accelerators uHing aupercunducting profect1ley. ${ }^{3}$ 1

Thiere in a blg ginag however: the perfornumcen 1llustrated In Fig.2 apply for superconductor temperaturen close to $4 \mathrm{~K}$. With fucrealing temperature the pinnlng force drops ripldly. Table I lintg che critical temporatures of the two commerctally avallable materlale, together whth the hiphest reported pinning forcas and the enthalpy difference between $4 K$ and $\tau_{c}$ for a if $T$ flelal. 
A heat input equal to the listed enthalpy difference will bring the pinning force to zero. About $10 \%$ of the enthalpy will suffice fur a reduction to $75 \%$ of the pinning force at $4 \mathrm{~K}$. Considerirg that expected final speeds are in excess of $50 \mathrm{~km} / \mathrm{s}$, corresponding to profectile energles of $>10^{7} \mathrm{~J} / \mathrm{cm}^{3}$, the accelerator is required to impart this energy to the superconducting profectlle with an efficiency $>10^{9}: 1$. Such an unusually tough requirement would Jeopardize the success. As an example: the ac loss of a superconductor for a $1 \mathrm{~kg}$ peak field $1 \mathrm{~s} 10^{-6}$ to $10^{-5} \mathrm{~J}$ per $\mathrm{cm}^{2}$ surface and per cycle; for a $0.8 \mathrm{~cm}^{3}$ profectlle with $1.5 \mathrm{~cm}^{2}$ surface 500 - 5000 cycles would already produce the tolerable (for $\mathrm{Nb}_{3} \mathrm{Sn}$ ) $10 \mathrm{~mJ} / \mathrm{cm}^{3}$ threshold.

Superconductors cannot be consliered as sultable projectlle materidl.

\section{Normal conductors}

Normal conductors can be used if the current decay time constint. is large enough compared to the acceleration time. For small profectiles this is not the case, as the foliowing example demonstrates. A cylindrical profectlle, $1 \mathrm{~cm}$ long, $0.5 \mathrm{~cm}$ dlameter and $0.5 \mathrm{~mm}$ wall thickness ( $I . \approx 2 j \mathrm{jh} ; \mathrm{R}=50 \mu \Omega$ at $\mathrm{RT}$ ) would have an $L / R=50 \mathrm{~ms}$; acceleration time to $5 \times 10^{4} \mathrm{~m} / \mathrm{s}$ at $10^{5} \mathrm{~m} / \mathrm{s}^{2}$ would be ten times larger. However, for larger projectlles (dlaneter $>5 \mathrm{~cm}$ ) normil conducting maturialy mily posetbly be an option.

\section{Ferromagnets}

For ferromagnetic profectile materlal the chaice is between ferrcus metals (Fe Co $\mathrm{N} 1$ and their alloys) or rare earth netals. The higher saturation Induction of the latter carries the penalty of a lower Curle temperature, as shown In table II. Choosing by as the most likely candidate the above mentioned efficlency of the acceleratur hat to exceed $10^{5}: 1$. While not trivial, this 18 a good deal less forbidding than the four orders of magnitude highor requiranent for superconductors.

\section{ACCLlera'ting forces}

\section{Ban 1c arrangementin}

Tho bastc componente of the proposed magnetic accelerator are indfatid II Fig. 3. The profectile $\Lambda$ it in the acrelerator tulie $B$. The profectile is

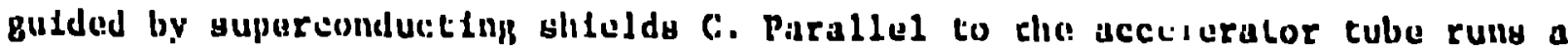


drive tube $D$ containing flux displacing colls $E_{;}$these are single colls spaced at regular Intervals along the tube. Both accelerator and drive tubes are surrounded by a superconducting (single layer) winding $F$ producing a longltudinal d.c. fleld. The windings are shorted by a longitudinal resistive conductor $G$; the shorts serve to give a good flux linkage to the drive colls $E$.

The device functions as follows. The d.c. field (orde- of $\mathrm{MA} / \mathrm{m}$ ) magnetizes the projectile. The drive colls energized in proper sequence by a sine wave current concentrate or dilute the flux in the accelerator tube, thus creating the accelerating wave. In the simplest casc, each drive coll is contacted with a charged capacitor and left to ring. More sophisti= cated switching, such as breaking the contact after one full cycle, is desirable to increase the energy efficlency. It is possible to combine accelerator and drive tube into one. The separation, however, has advantages of design flexibllity, besides higher amplitudes of the magnetic wave due to the transformer action.

The principle of levitation and guldance is lllustrated in Fig. 4 . The field $H$ induces the magnetization of the projectile. The supercouducting surface does not allow penetration by any magnetic flux; the approaching projectlle Induces a current pattern preventing flux penetration. The Induced current pattern distorts the flux distribution in the same manner as a mirror image of the projectile would do. The repulgive force between projectilo and induced current pattern (mirtor 1mage) provides the stable guldance and prevents the uttraction of the projectilo to the current loops.

It 1s interesting to reflect on the fact that a superconducting profectile, used as a perfect diamagnet, wnuld not need a gutde shiedrl; but for a ferromagnet, or a permancut magnet, there 18 no stable suspension witliout a gulde shleld. Earnshaw's theorem, stating that there is no stable muchantcal equilibriun for an unconytrnined charge in the stutic fleld of other chargey, to also vald for permanent magnets ingtead of clirges, and also for feiromagnats and trangport current digtributions. The theoram does not apply to dlamagnetic materl.11; it can also be evided by combinius diamignetic and ferromagnetic materials as was dlycussed by M. Bevir. ${ }^{4}$ 
The superconducting guide sheet is therefore necessary, If a complicated servo guiding oystem is to be avolded.

Of course, the gulde sheet need not necessarlly be superconducting: a righ conductivity metal will do just as well provided the decay time constant for the Induced current pattern Is long compared to the passage of the profectile, an easily achlevable condition. However, non superconducting sheets cause drag.

The guide shcet has to be open because it forms a barrier to changes In radial flux component, and such changes are essential for the establishment of a traveling magnetic wave. It is suggested that the guide tube is in two, or more, symmetric parts to give a symmetric magnetic fleld distribution at the profectile position. The longltudinal openings in the guide sheet may be helical to give net guidance in all directions along the flight path. The guide sheet will need careful enfineering, also, the calculation of guide forces is a difficult problem.

An approximate estimate of the force between gulde sheet and projectlie (as lised in Fig. 7) Is obtained as follows. With the p:ojectile touching the gulde sheet one can assume that a magnetic pressure of $\mathrm{b}_{\mathrm{g}}^{2} / \mathrm{w}_{0}$ is acting over half the projectile surface facing the superconductor. ( $P_{8}$ Is saturation Induction, $\mu_{0}-4 \pi \times 10^{-7} \mathrm{Vs} / \mathrm{Am}$; for dysprosium the pressure beromes approx. 4.9 MPa.) This will give the maximum avallable force. For larger sepalation the force is proportional to $d^{2}$ (see Fig.4).

\section{Driving acceleration}

To estimate the highest achievable acceleration tic arrangement 11lustrated In Fig.5 is conuldered. Each flux displacing coll is connected to a sharged capacitor $C$ by a swtch operated at the right time. The single wire loor of $10 \mathrm{~cm}$ dlameter and $2 \mathrm{~mm}$ wire dianeter has an inductance of $\mathrm{L}-$ $0,27 \mu H$. A change of average Induction of $0.2 \mathrm{~T}$ in the drive luop represente a flux change of $\Delta \phi-1.6 \mathrm{inVs}$. Thls needs a drive current $I_{p}-\phi / \mathrm{L}-6 \mathrm{kA}$. The augnetic wava length determines the time constant thus: $\pi \sqrt{L C}-\Delta t=d / v$, wth $d-2 \mathrm{~cm}$ and $v=10^{5} \mathrm{~m} / \mathrm{s}, J t=0.2 \mu \mathrm{s}$ and $C=d^{2}\left(\pi^{2} v^{2} u\right)^{-1}-0.015 \mu F$ and the necessury chaiglng voltage becomes $v=L d I / d t=L_{\pi} I_{p} / \Delta t=25 \mathrm{kV}$. It Is seen that these are all quite manageable values and not beyond the stnte-ol-the-irt.

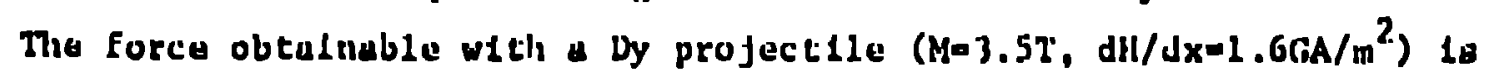


$5.6 \mathrm{GN} / \mathrm{m}^{3}$ and the acceleration a $-6.6 \times 10^{5} \mathrm{r} / \mathrm{s}^{2}$ or $\$ 500 \mathrm{~km} / \mathrm{s}^{2}$.

At this acceleration a spetd of $50 \mathrm{~km} / \mathrm{s}$ can be reached in a length of $2.5 \mathrm{~km}$.

Two important effects have not been taken into account in tiils simple calculation. One is the effect of the mutual inductances between the drive colls, the other the elfect of the changing inductance due to the moving projectile. The former can be minimized by disaligning nelghborlng flux displacing loops as indicated in Fig.5. The latter can be minimized hy making the projectile small. Energetic considerations give a simple estimate for the tolerable size of the profectile. With the above values the energy stored in each charged capacitor is close to $5 \mathrm{~J}$, adding up to $5 \mathrm{~kJ} / \mathrm{m}$ along the accclerator. At the above force the energy needed per units of length of accelerator and projectile volume $185.6 \mathrm{cJ} / \mathrm{m}^{4}$, Implying that the projectile has to be much smaller than $10^{-6} \mathrm{~m}^{3}(\sim 8.5 \mathrm{~g})$. A feu percent of this, $1 . e$. a profectile of the order of $100 \mathrm{mg}$ m1l not substantially reduce the shove calculated forces.

The large number of switches can be avnided by making use of two arrangements for the produrtion of magnetic waves as previously used for the acceleration of plasmas. One is a lumped parameter transmission line: the example described by Bleger et $a{ }^{3}$ has the following approximale dimensions: length $60 \mathrm{~cm}$, colls of $6 \mathrm{sm}$ diameter spaced $2.5 \mathrm{~cm}$. A magneltc gtep wave is produced with a fleld rise of $2.5 \mathrm{kG}$ in approx. $4 \mathrm{~cm}$, it travels with a speed of $2 \times 10^{5} \mathrm{~m} / \mathrm{s}$ at the entrance and $8 \times 10^{5} \mathrm{~m} / \mathrm{s}$ at the exit of the structure, 1.e. an acceleration. of $5 \times 10^{11} \mathrm{~m} / \mathrm{s}^{2}$ is achieved by decreas $1 \mathrm{np}$ capacities and the Inductance of the colls with increasing length position. The other, similar arrangement, is a hi:11cal trangmission line. The one descrlbed by Mafleld et al ${ }^{6}$ has 13.2 turns $/ \mathrm{m}$, a diameter of approx. $10 \mathrm{~cm}$ and produces an axial field step of $7 \mathrm{~kg}$ traveliting at a gpeed of $1.65 \times 10^{5} \mathrm{~m} / \mathrm{s}$. Capacitors of $0.5 \mu \mathrm{F}$ at $2.5 \mathrm{kV}$ are used.

1 Both lumped paremeter or hellcal transmission lines can be used with 11ttle further development as flux displacinp drivers (colls E In Fig.3). 'The advantage is that a glingle owltch can take care of a length of accelerator of $1 \mathrm{~m}$ or longer. The accelaration can be achieyed with inductances and Lapcitors that decreasc with Increasiug position coordinate or else with Incrensingly smaller upacing of the flux IInking collg (F in Fig.3). The 
anticlpated problems will be dispersion and reflection of the step wave and Insufficlently sharp step. 7 These will probably limit the length of such structures to the order of meters.

\section{Gulding force for circular accelerater}

The aption of a rircuiar accelerator is avallable because the guiding force can be used to produce the centripetal acreleration $a_{c p}-\omega^{2} R=v^{2} / R$ necsssary to keep the profectile with the speed $v$, or angular speed $w$, on a circle with radius $R$. The centripetal force $F_{c p} a_{c p}{ }^{m}$ is produced by a combination of attraction and repulston. The attraction is obtained by the largest possible gradient $d H / d r$, with $H$ being at the same time the magnetizing fleld for the ferromagnetic projectile. Repulsion is produced by a super= corducting guideway, necessary for stable suspension.

In Fig. 6 a typical arrangement for the production of a strong guiding force is shown. The projectile $A$ is magnetized and attracted by the fleld of a current flowing in the conductor B. The diamagnetic gulde C repels the projectile. Drive colls $D$ produce the magietic traveling wave.

Naturaily, there is a great deal of scope for Investigating and devclopping such arrangements. Applications not on!y for accelerators but also for levitated transportation, for high and low speeds, can be contemp= lated. 8

Two calculated examples give an eatimate for the possibilities of the centripetal driving force. In $F_{F}, 7$ and $b$ the attractive and the repuloive force and the resulting sum of the two versus the radial position of the projectile is given. The right hand or:llinute indicutes a for the projectilu of $120 \mathrm{mg}$ masg in Fig. 7a, or $60 \mathrm{mg}$ in 7b. It $1 \mathrm{~g}$ ragsonable to expert acp in excess of $10^{6} \mathrm{~m} / \mathrm{s}^{2}$. With ap $2000 \mathrm{~km} / \mathrm{s}^{2}$ the ridlus of an accelerator for speeds of $50 \mathrm{~km} / \mathrm{s}$ becomeu $1.25 \mathrm{~km} . *$

- The city of Baplidad as urf.pinaily bullt between 762 - 766 AD undor Al Manuur was perfectly circular and almost cxacliy this siee. Of courac, there are: several modein particle accelcratois of clrcular vhape and sinflar slze, elther already bullt or planned. 
IV. SOME OPTIONS

For a clrcular accelerator the striving for a high driving acceleration is considerably relaxed. There are posstbilities to use sultchless energy transfer ${ }^{9}$ to the driving colls. As the angular speed of a projectile travelling at $50 \mathrm{~km} / \mathrm{s}$ around a $2.5 \mathrm{~km}$ diameter circle is only $42 \mathrm{~s}^{-1}$, or $6.6 \mathrm{rps}$, one can use a rotor as a flux displacer (in place oi capacitors and single turn colls $E$ as in Fig. 3). For this purpose the colls F (see Fig.3) are arranged around the periphery of a small circle in a way as to link the flux from the pole tips of a special rocor, as 1llustrated 1r. F18. 8. The geometric relationshlp $d / D=r / R$ has to be fulfilled. Tak1r:b $d=1 \mathrm{~mm}$ as a lowest practical 1 Imit gives possible dimcnsions for $t$ and $D$ as in Table III. Assuming a pole flux of $1 \mathrm{~T}$ and $h=5 \mathrm{~m}$ the driving acceleration as stated is obtalned.

The rotor in the shape of an arbor produces two accelerating magnetic waves enabling the simultaneous acceleration of two projectiles. The rotor can have more poles for the simultaneous acceleration of more profectiles if desirable.

The connection between ilux- and drive loops is made with special low Inductance cable, such as copper films on both sides of a 1 mil Kapton $f 11 \mathrm{~m}$ capable of withstanding $7 \mathrm{kV}$. A $10 \mathrm{~cm}$ wide cable has an inductance of $3 \times$ $10^{-10} \mathrm{H} / \mathrm{m}$, or $0.3 \mu \mathrm{H} / \mathrm{km}$, which $1 \mathrm{~s}$ only a fraction of the incluctince of fluxand drive colls of the order of $\mu \mathrm{H}$.

A further development of the rotor Idted leads to a relaxation of the constralning condition $d / D \cdot r / R$. The flux loops can be linld out around the periphery of the rotor on a epiral with two turny as sketched in Fig. 9. The splral arrangeenent can be made with more than two turns and correspondingly higher rntor speeds. The results of Table IV apply if the same rotor ( $h-5 \mathrm{~m}$ and $B-1 \mathrm{~T}$ ) as $\mathrm{in} F \mathrm{gg} .8$ and flux loops with $d-3 \mathrm{~mm}$ and $\mathrm{r}-1 \mathrm{~m}$ arc used. The cise 11 luatrated In Fig. 9 has 4 oimultaneous accelerating

The pole tip consists of two vertical parallel edges very close to each other, each belng 1 mom wide. One has a flux deugity of $+1 T$, the other of - $1 \mathrm{~T}$. It is assumed that the linkage with the stator flux colls is about $80 \%$ so that thesc would experlence a net ilux change of $1.6 \mathrm{~T}$ as the rotor tip piaseg over them. 
waves golng around. More $s$ imultaneous waves are possible with $n>2$.*

The rotor drive concept cou!d, in principle, also be used to energlze a IInear accelerator, but it will be difficult to obtain the high acceleration desirable.

Ilsing the accelerator for Impact fuston it would be of advantage to have four simultaneously accelerated projectiles impacting on each other along the diagonals of a tetrahedron. For this purpose the projectiles are extracted along tangents and then guided along curved paths (twisted s-curves) of equal. length and equal, palr-wise mirror symetrlc shape as llistrated In Fig. 10. These guide ways have by necessity a radius of curvature $<R / 2$ and can therefore not be handled by the same superconducting structure that produces the a during acceleration. Normal conducting and correspondingly high current3 of a short duratlon can produce the high attractive forces necessary for this purpose.

\section{v. CONCLUSION}

It Is posstble to accelerate small ferrumagnetic particles with linear acceleration of $\sim 500 \mathrm{~km} / \mathrm{s}^{2}$ or more, or centripetal acreleracton of $\sim 2000 \mathrm{~km} / \mathrm{s}^{2}$. producling speeds of $50 \mathrm{~kg} / \mathrm{s}$ in linear accelerators of $2.5 \mathrm{~km}$ or less length, or circular accelerators of $2.5 \mathrm{~km}$ diameter. Higher speeds are possiblc with larger accelerators. The profectile mass can be approx. $100 \mathrm{mg}$.

For comparison, the hlghest velocitles, obtalned from light $8 \cdot z$ guns, for projectiles of similar size have been reported 10 to approach $13 \mathrm{~km} / \mathrm{s}$ which may be a $l i m i t$. Circular accelerators have the advantage that a smaller driving acceleration
Projectiles of higher mass arc possible with linear accelerators. can be employed. This allows the use of switchless and more efficlent methods of energizing the accelerating magnetic wave by means of a retor.

- To have unuged magnetic waves clrculating may be disadvancogeous bernuge of ac losses in the superconductor. If only 4 projectiles are neaded the rocor may be programed that only that part is energlzed whtch is neejed for tiae 4 active accelerating waves. 


\section{REFERENCES}

1 F. Winterberg, Magnetic Acceleration of a Superconducting Solenold to Hypervelocities", Plasma Physics, $8,541-552,(1966)$

2 D. Anderson, S. Clafl11, F. Winterberg:"On the Acceleration of a Superconducting Macroparticle in a Travelling Magnetlc Wave Accelerator" 2. Naturforschg. 26a, 1415-1424 (1971) see Proc. of the Impact Fusion Workshop,July 1979, Report I.A-8000-C also: F. L. R1be, A. T. Peaslee, Flral Report UdFPP-7, Jan.1930; App.B (bj R. Marrs)

4 M. Bevir, Culham report $1975 / 1976$ (In ref 7 this $1 \mathrm{~s}$ referred to as "to be published (1977))

5 W. Bleger, H. Gresser, F. Hoenen, R. Lyuter, F. Richter, A. Stampa and H. Tuczek:'Untersuchungen zur Beschleunlgung von Plasma mit elektromagnet1schen Wanderwellen", Z. Naturforschg. 23a, 263-270 (1968)

6 E. B. Mayfield, R. X. Meyer, R. M. Head, R. H. :luddlestone:"rlasma Propulsion by means of a Helical Transmission Line", pp.543-555 in Electric Propulsion Development, ed. E. Stuhlinger, Acad. Press 1963 (Am. Rocket Soc., El. Prop. Conf., Barkelay, 1962)

7 J. Marshall, private comm. (1980). (see also: J. Marshall:"Acceleration of plasma Into vacuum", 2nd Conf. Peaceful Uses of Atomic Energy, Geneva, 1958, Vol. 31 Pp. 341-347)

8 G.J.Homer, T.C.Randle, C.R.Walters, M.N.WAlson, M.K.Bevir, "A New Method lor Stable levitation of an Iron Body Using Superconductors."

J. Phys. D,10,879-866(1977)

9 S. I.. Wipf, "Kev. csible Energy Transfer between Inductances", Proc. Int. Conf. on Encrg̣j Storage, Compression and Swlroning, Italy, 1974, ed. W. H. Bostick, V. Nard1, O.S.F.Zucker, P!enum Press, 1976,pp.469-475 Prozir. In dotronastles and íeronatics, 1979, Am. Inst.Aeron.dast ron. 


\begin{tabular}{l|l:l|l|l|} 
& $T_{c}$ & $F_{p} \max (4 K)$ & $T_{c}(L: T)$ & ${ }_{4} S_{c}{ }_{c}^{(4 T)} d T$ \\
\hline$N b T_{1}$ & $9-10 \mathrm{~K}$ & $1.5 \times 10^{10} \mathrm{~N} / \mathrm{m}^{3}$ & $7.3 \mathrm{~K}$ & $10 \mathrm{~mJ} / \mathrm{cm}^{3}$ \\
\hline $\mathrm{Nb}_{3} \mathrm{Sn}$ & $16-18 \mathrm{~K}$ & $4.5 \times 10^{10} \mathrm{~N} / \mathrm{m}^{3}$ & $14 \mathrm{~K}$ & $100 \mathrm{~mJ} / \mathrm{cm}^{3}$ \\
\hline
\end{tabular}

TABLE II LIMITS OF FERROMAGNETIS MATE..IALS

\begin{tabular}{llccc} 
& $\delta$ & $M_{s}$ & $T_{c}(4 T)$ & $\int^{T} c_{c d T}$ (est.) \\
FERROUS & 7.8 & 2.5 & 1100 & $200 c$ \\
\hline Od & 7.9 & 2.7 & 280 & 500 \\
Tb & 8.3 & 3.4 & 240 & \\
Dy & 8.5 & 3.7 & 120 & 100 \\
Ho & 8.8 & 3.6 & 35 & 1 \\
Er & 9.0 & 2.8 & 32 &
\end{tabular}


TABLE III ACCELERATION DATA FOR ROTOR ENERGIZER (see F1g.8)

\begin{tabular}{|c|c|c|c|c|}
\hline $\begin{array}{c}r \\
{[m]}\end{array}$ & $\begin{array}{c}D \\
{[m]}\end{array}$ & $\begin{array}{l}\mathrm{dH} / \mathrm{dx} \\
{\left[\mathrm{A} / \mathrm{m}^{2}\right]}\end{array}$ & $\begin{array}{c}\mathrm{a} \\
{\left[\mathrm{m} / \mathrm{s}^{2}\right]}\end{array}$ & (for $R=1.2 \mathrm{~km}$ ) \\
\hline 1.5 & 0.8 & $1.3 \times 10^{7}$ & $5.6 \times 10^{3}$ & \\
\hline 2 & 0.6 & $2.3 \times 10^{7}$ & $10^{4}$ & \\
\hline
\end{tabular}

TAHLE IV ACCFLFRATION DATA FOR SPIRAL STATOR WITH "IURNS (see Fig.9)

$$
(d=3 \mathrm{~mm} ; \mathrm{K}=1.2 \mathrm{~km} ; \quad \mathrm{r}=1 \mathrm{~m})
$$

\begin{tabular}{c|c|c|c|c}
$n$ & $\begin{array}{c}v \\
{[\mathrm{rps}]}\end{array}$ & $\begin{array}{c}\mathrm{dilidx} \\
{[\mathrm{m}]}\end{array}$ & $\begin{array}{c}\mathrm{a} \\
{\left[\mathrm{s}^{2}\right]}\end{array}$ & {$\left[\mathrm{m}^{2}\right]$} \\
\hline 2 & 13.2 & 1.8 & $3.7 \times 10^{6}$ & $1.6 \times 10^{3}$ \\
0 & 40 & 0.6 & $1.1 \times 10^{7}$ & $4.8 \times 10^{3}$ \\
10 & 66 & 0.36 & $1.85 \times 10^{7}$ & $8 \times 10^{3}$ \\
14 & 91 & 0.26 & $2.5 \times 10^{7}$ & $1.1 \times 10^{4}$
\end{tabular}




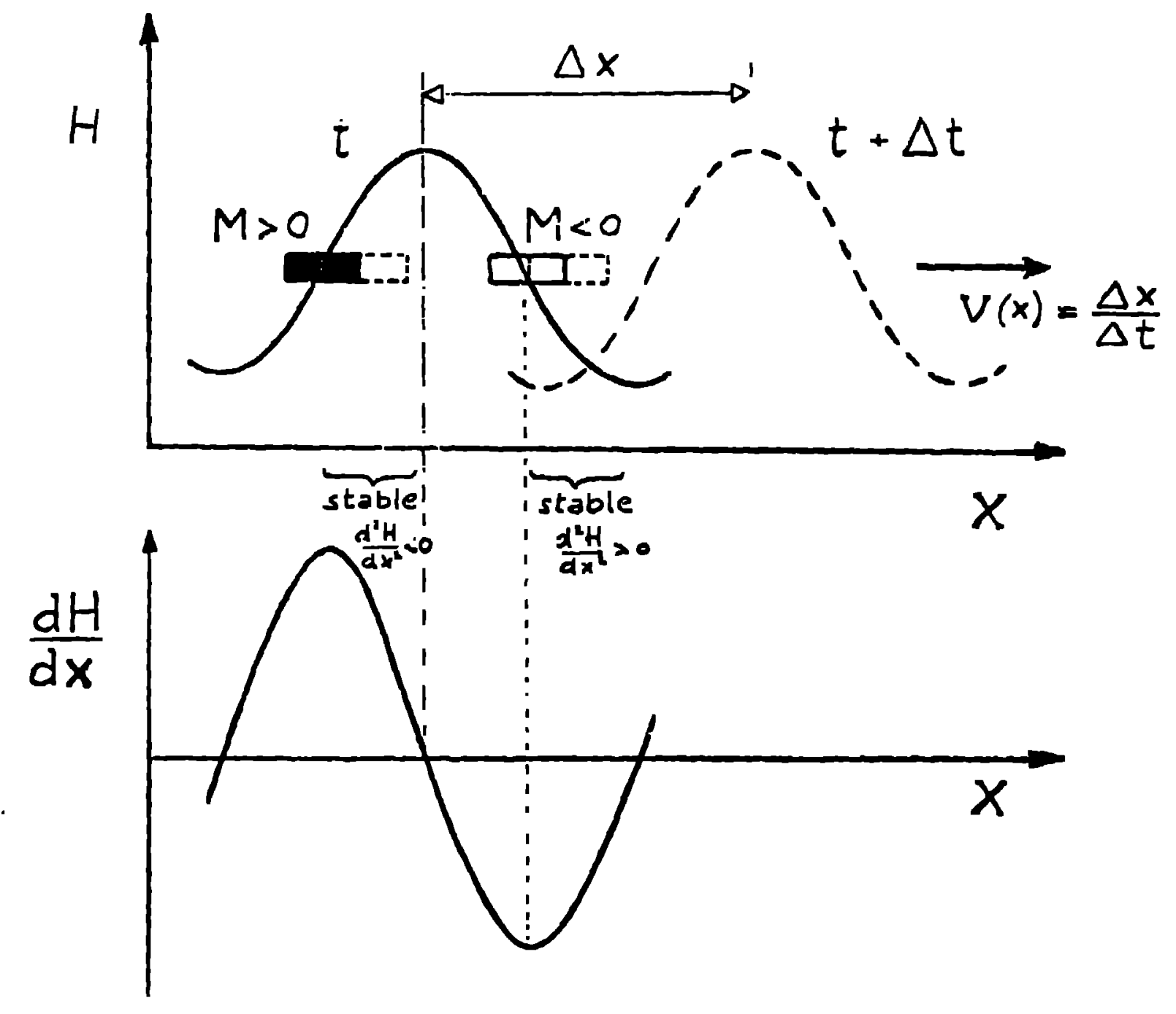

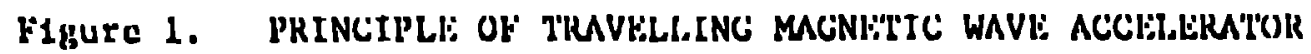




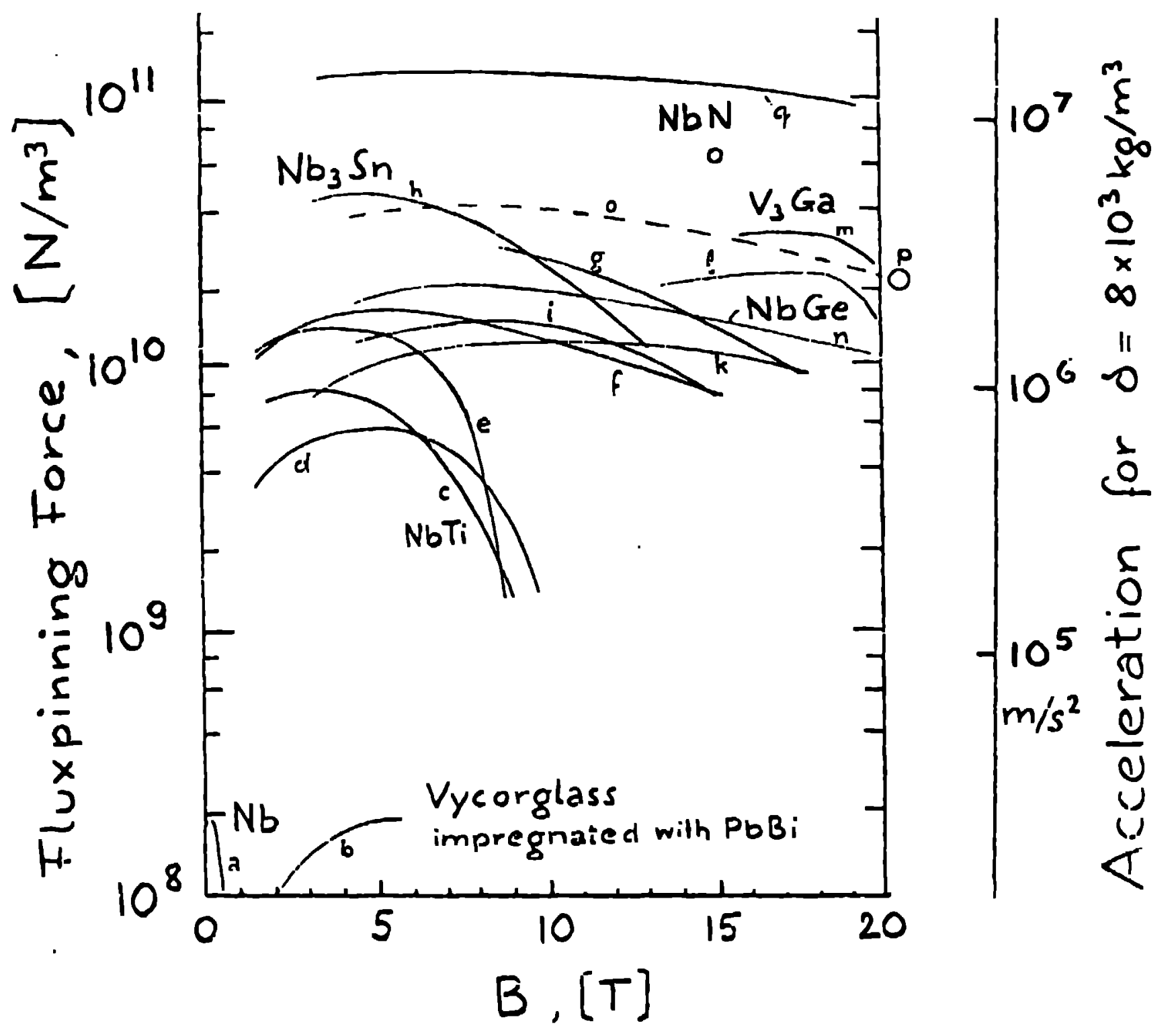

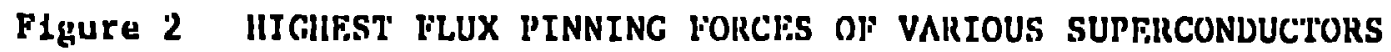
ANI) CORRHSPONUTNG ACCLLLER'ITON OHTAINAHLE

n Nb, 1riadlated (S. T'. Sckulil, J.appl.phys. 42, 1.6 (1.971))

b Porous glass, Pblit 1mpregnated (J.ll.P. Whtson, J. Appl. Phys.42,46(1971))

c. Nb-78\%i'1 (Mctnturff et a1. J.Appl.Phyн. 38,524(1967))

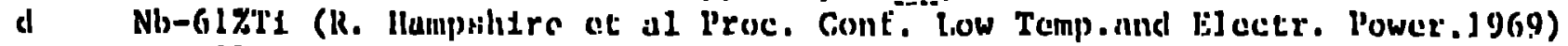

e Nb-10\%\%-10\%'L (T'. Do1 et al Tranz AIM: 2/,2.1793 (1968))

f $\quad \mathrm{Nb}, \mathrm{Sn}$ tapo $(22$ (;Y) 15, L(iC)

8 Nb 3 Sn tape (M. (A. Bene, Iblik' 'Trann. MAG-2,760(1960))

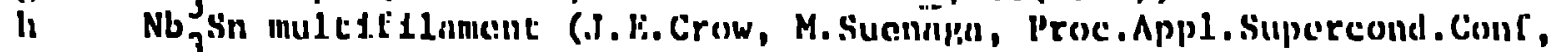
Amupo11a, 1972, Iflil: Pub. 172CHo682-5-2'ABSC, p. 472)

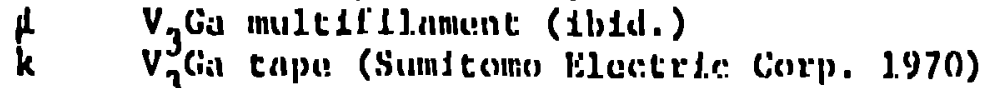

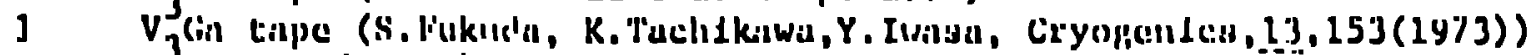

ill $\quad v_{\text {Giat } \% \text { r }}$ (1blıl.)

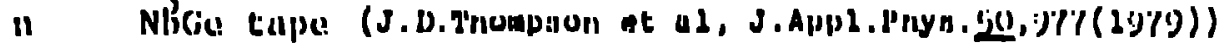

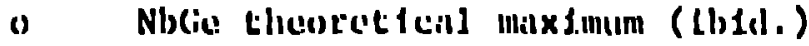

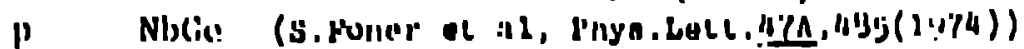

q NGN Ellin (J.R. Giavader et al J.Appl.Pliys.42.54(19\%1) 


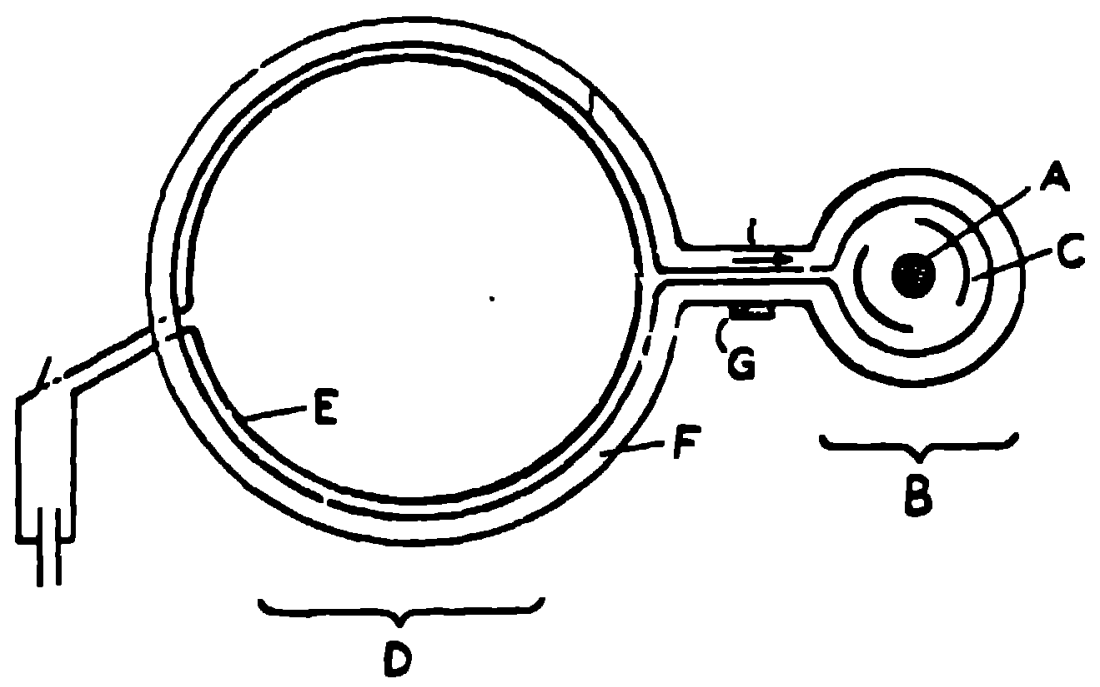

Figure 3 CROSS SECTION OF CONCEPTUAL ACCELERATOR (see text)

$\begin{array}{ll}\text { A } & \text { Projectile } \\ \text { B Accelerntor tube } \\ \text { C Superconducting gilde shields } \\ \text { D Drive tube } \\ \text { E Flux disp!acing cotis } \\ \text { F Fleld winding (superconducting) } \\ \text { G Reglative turn to turn short }\end{array}$

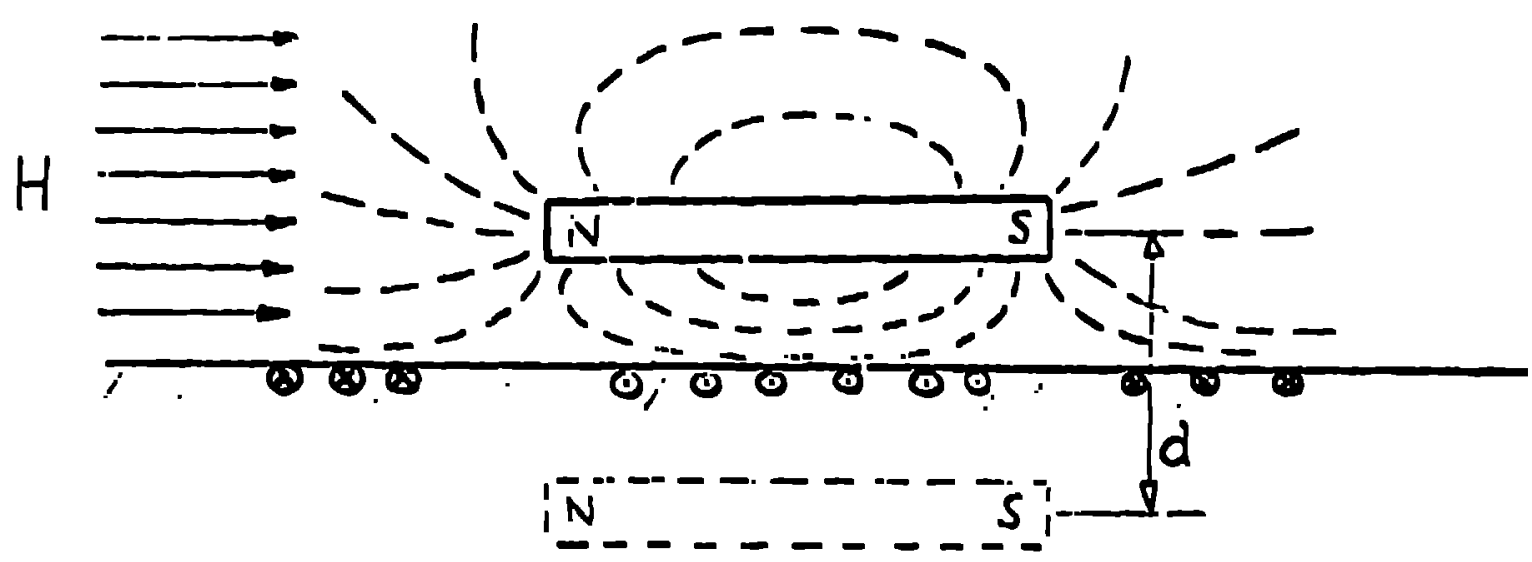

Fadure 4 PRINCIPISE OF GUIDING FORCL: 


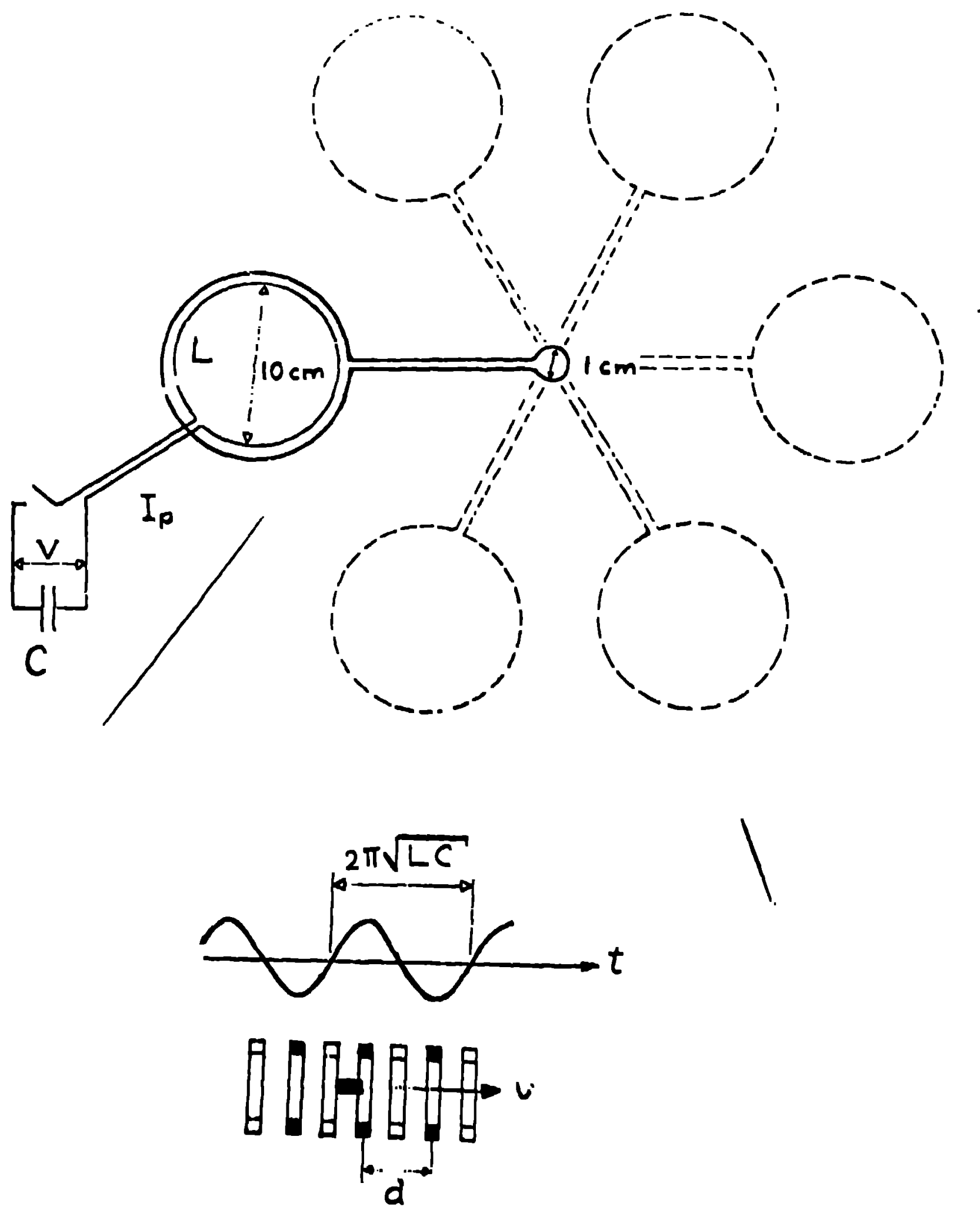

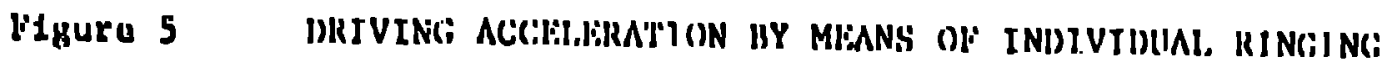
L-C Bhlaskinits 


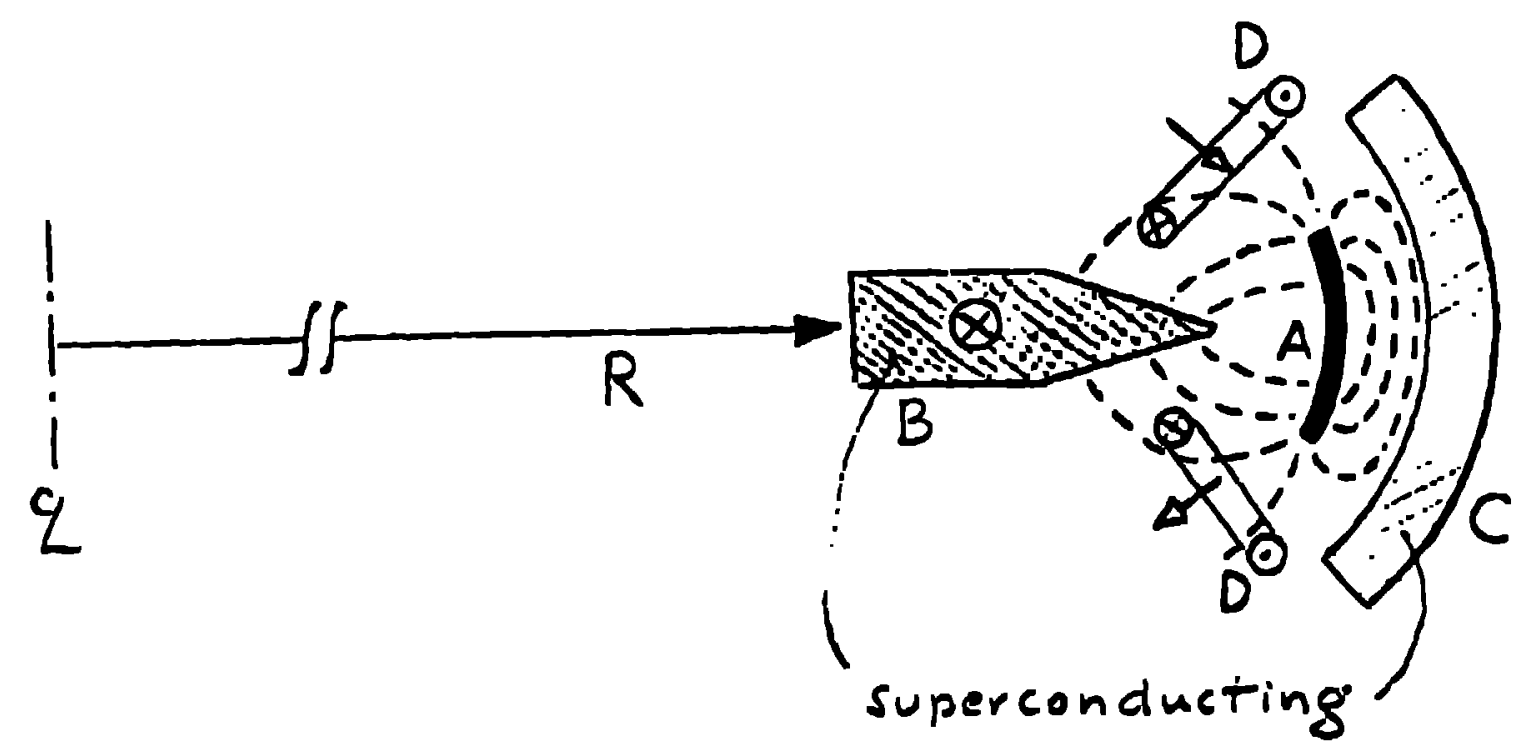

Figure 6 SCHBMATIC OF CIRCULAR GUIDSNCE AND ACCELLBUTION ARMATURE 


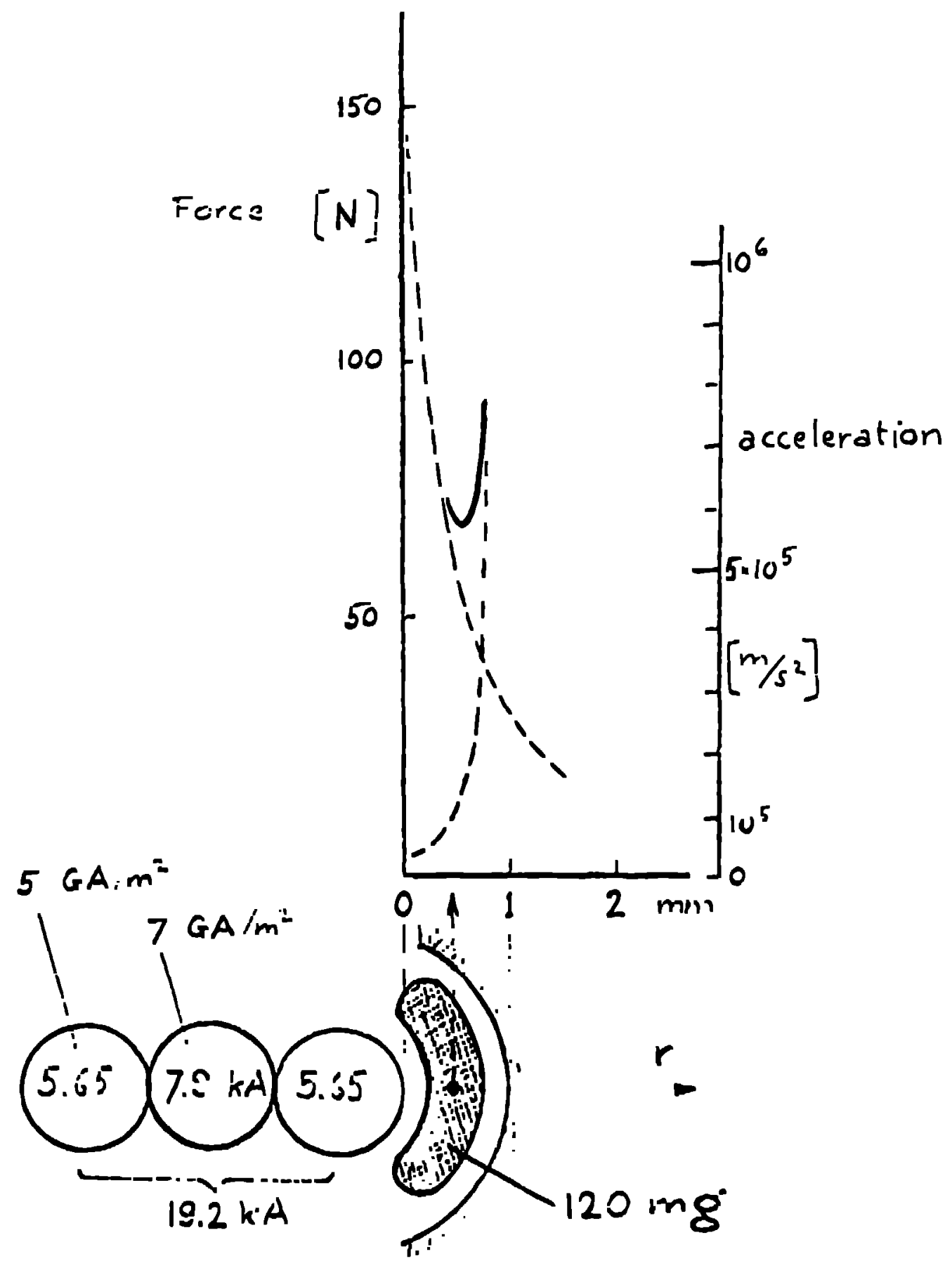

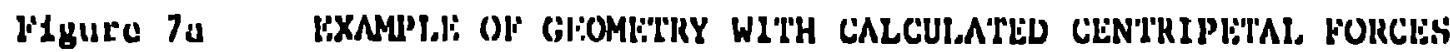
AND ACCHALIKA'LION

Soldel curva: sum of attractelvi: and repulatve fores versus radlas posttion of projectile. Stuble :uspous Lon posistblo 11 alacendling parte of curve. 


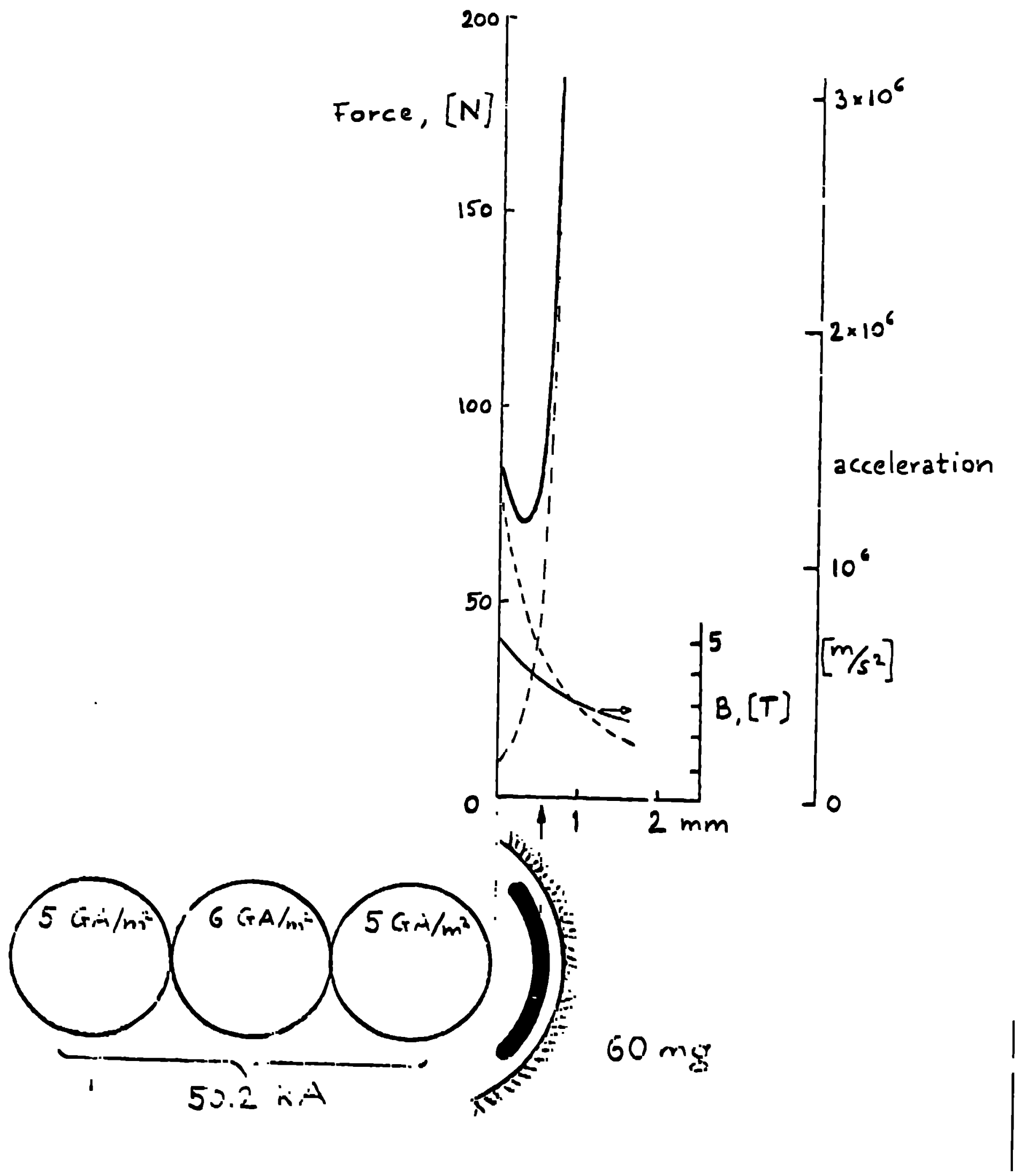

Figuro 76 SECOND LXAMPLE (Heu Fig. 7a) 


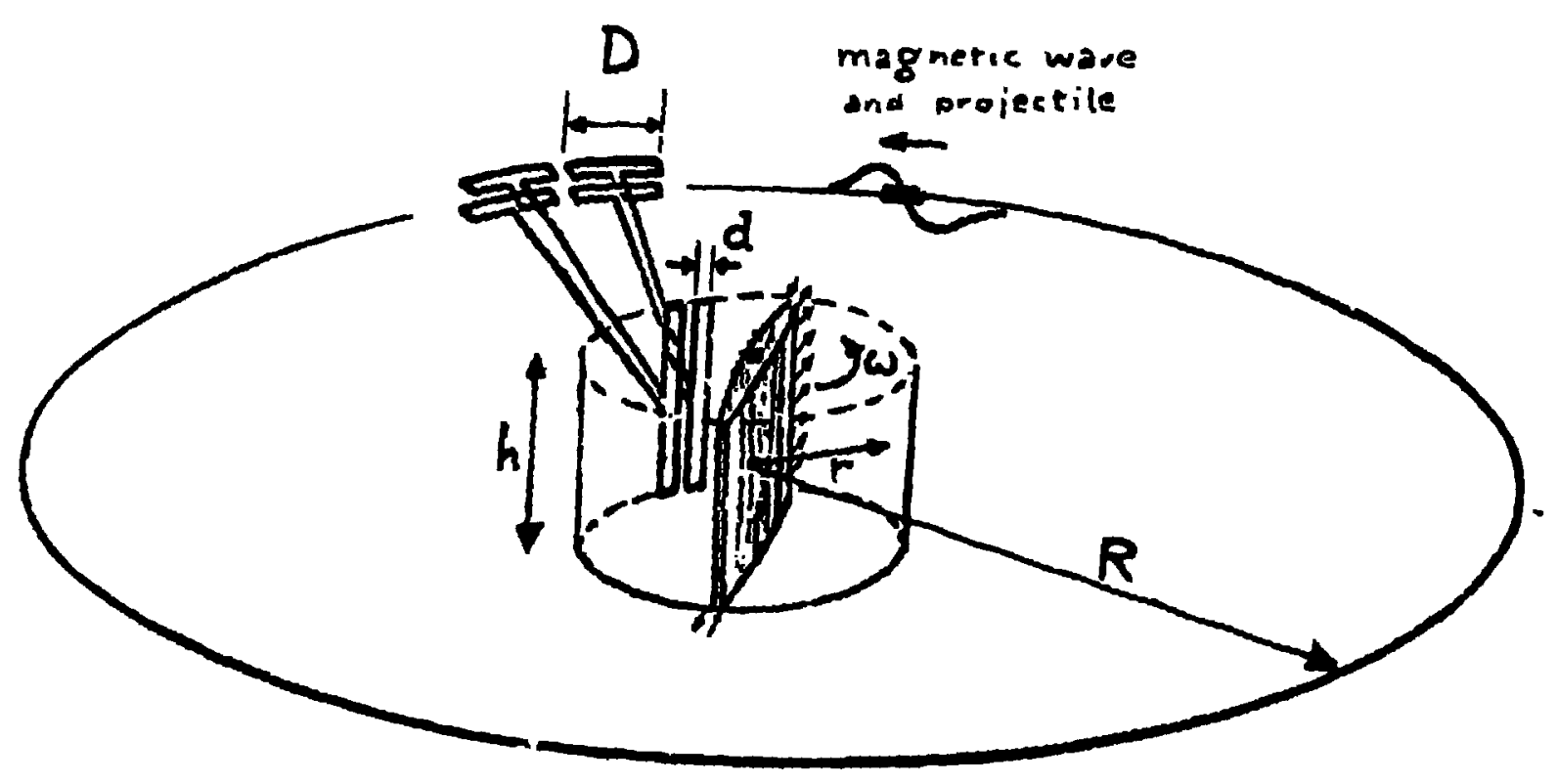

FIgute 8 PRINCIPLE OF OBTALNING DRIVING ACCELERATION FROM ROTOR

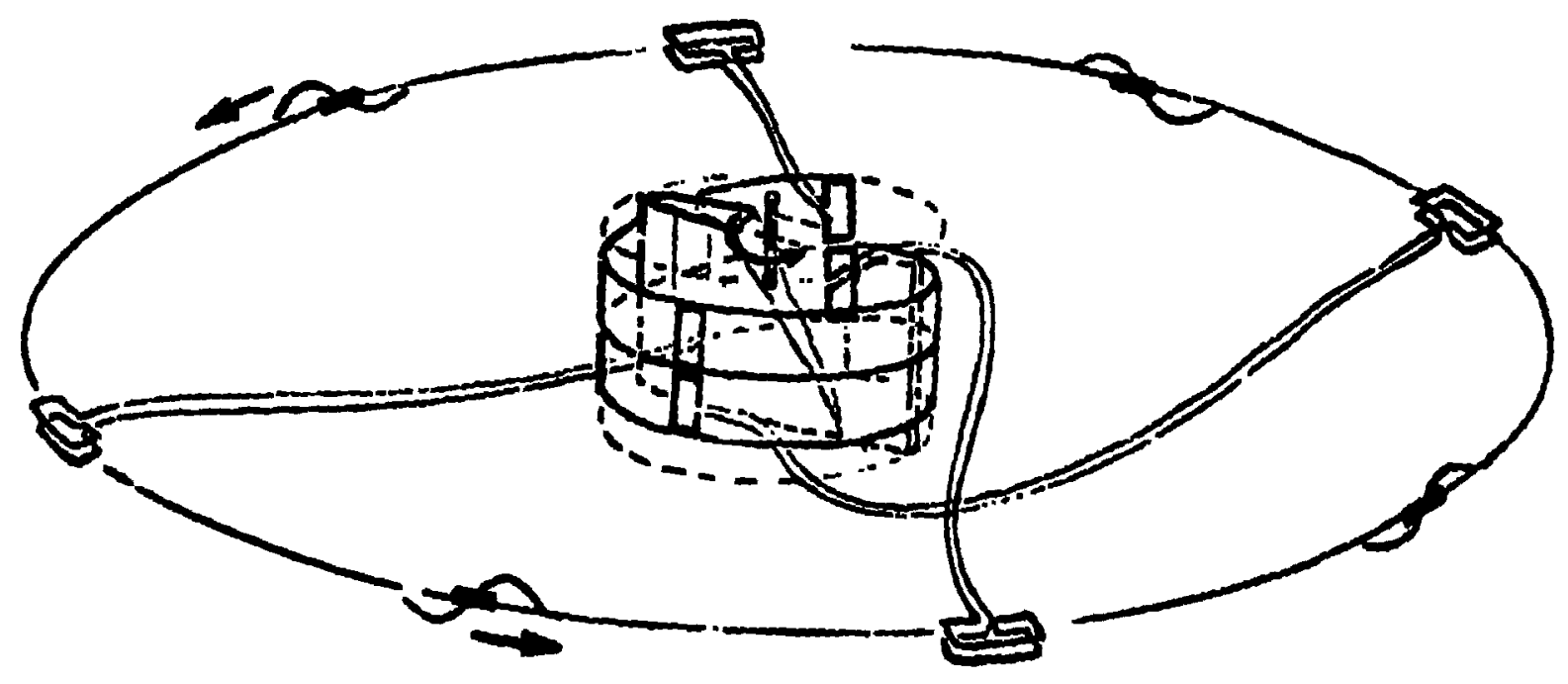

Figuro 9 HLux uIsplaclih witI spikal statok 


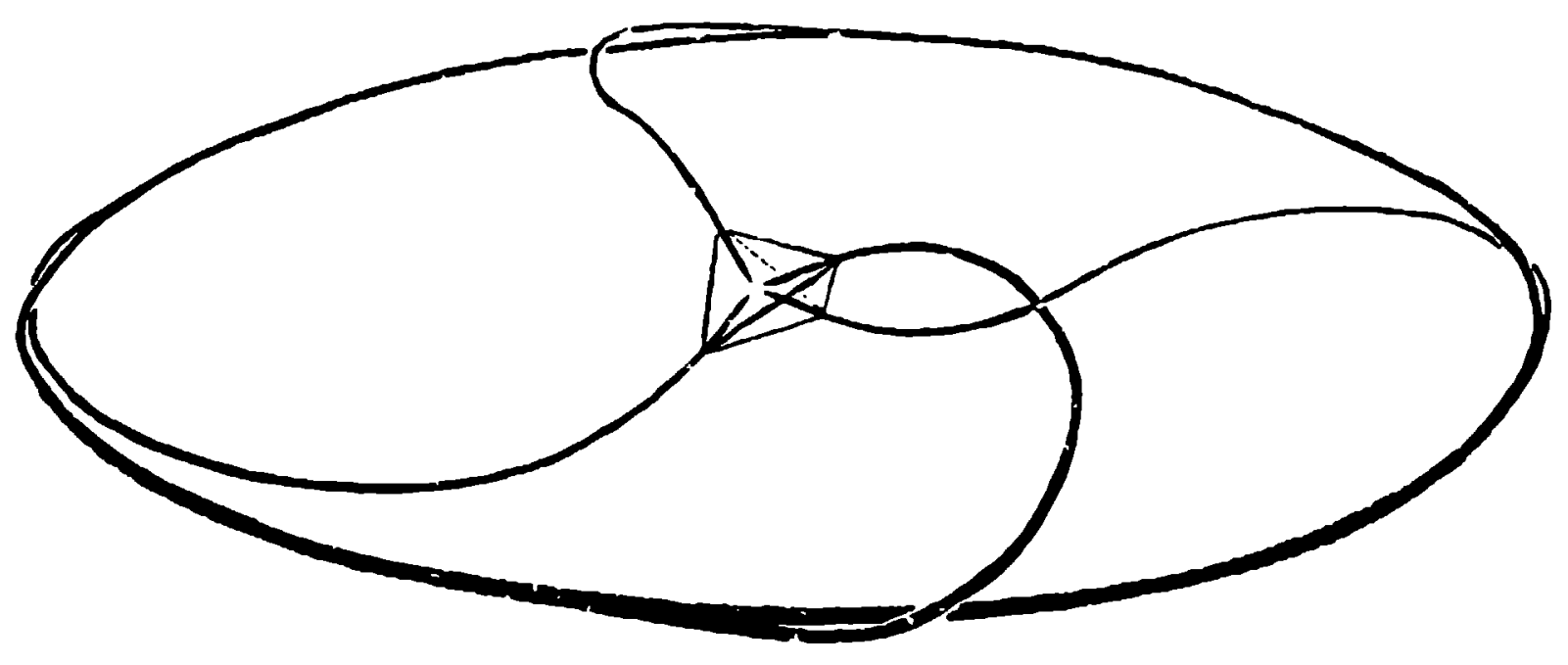

Figure 10 LAYOUT OF ACCBI.KRATOR FOR FOIJR PROJFCTIILSS

SITULTANEOUELY IMPAC'TING ON EACH OT'HER. 